\title{
Adult polycystic kidney disease and linked R
at the $\alpha$ globin locus: a genetic study in the South Wales population
}

L P LAZAROU*, F DAVIES + , M SARFARAZI*, G A COLES $\dagger$, AND P S HARPER*

From *Institute of Medical Genetics, University of Wales College of Medicine, Heath Park, Cardiff CF4 4XN; and the Department of Renal Medicine, University of Wales College of Medicine, Cardiff Royal Infirmary, Newport Road, Cardiff.

SUMmaRY Thirteen South Wales kindreds with adult polycystic kidney disease have been studied for genetic linkage using the $\alpha$ globin and $3^{\prime}$ HVR probes. A maximum lod score of $24 \cdot 187 \stackrel{\circ}{工}$ was found at a recombination fraction of $0 \cdot 03$. This study supports the existence of a single locus on chromosome 16 responsible for the disorder.

Adult polycystic kidney disease (APKD) is an autosomal dominant disorder, displaying variable age at diagnosis and severity. ${ }^{2}$ The incidence is around 1 in 1000 births $^{3}$ with a mutation rate of $6 \cdot 5$ to $12 \times 10^{-5} \cdot{ }^{4}$ It is a common and often potentially fatal multisystem disorder, the major abnormality being the progressive enlargement of cysts in several organs, primarily the kidney, resulting in chronic renal failure. It accounts for approximately $9.5 \%$ of the total dialysis and transplant workload of the renal units in South Wales, thus proving a substantial economic burden. ${ }^{5}$ The basic biochemical defect is as yet unknown, ${ }^{7}$ and current therapy is ineffective in the retardation of cyst development. In the past, gene carriers were discovered when they were symptomatic or had affected offspring. Recently, ultrasonographic scanning (USS) has been used to identify patients presymptomatically, but a normal result cannot be relied upon under the age of 30 years. The earlier detection of gene carriers is important in allowing accurate genetic counselling and giving reproductive choice, including prenatal diagnosis, to those found to carry the gene. Those found not to carry the gene can be reassured and can be considered, if they wish, as potential transplant donors for affected relatives. Earlier detection of the gene may also encourage regular monitoring for the recognition and treatment of such problems as hypertension and urinary infection, thus helping to preserve renal function.

Until recently the chromosomal localisation of

Received for publication 11 April 1987

Revised version accepted for publication 19 May 1987.
APKD was unknown, but through DNA technology: it has been localised by Reeders et al ${ }^{8}$ to chromo some 16 , using a hypervariable sequence (3'HVR) which lies $\sim 8 \mathrm{~kb}$ from the $\alpha$ globin gene cluster. The study was based on nine families giving a maximum lod score $(\hat{Z})$ of 25.85 at a recombination fraction $(\hat{\theta})$ of $0 \cdot 05$. Since this linkage was published, a protein polymorphism of phosphoglycolate phosphataseo, $(\mathrm{PGP})^{9}$ has been found to be closely linked to $A P K D$ ( $P G P$ vs $\alpha$ globin cluster, $\hat{\mathrm{Z}}=8.21$ at $\hat{\theta}=0$ $P G P$ vs $A P K D \quad \hat{\mathrm{Z}}=11.61$ at $\hat{\theta}=0)$. The results obtained by Reeders et $a l^{9}$ suggest a single locus for the APKD gene; however, the families were limited in number. Further family studies in different populations are required to confirm their origina findings.

This report analyses South Wales APKD families with the 3'HVR marker and polymorphisms within the $\alpha$ globin locus, the study forming part of $a$ broader genetic and population study of the disorder in the region.

\section{Materials and methods}

A total of 139 families was identified from the dialysis and transplant registers of the Cardiff Royalo Infirmary Renal unit (serving a population of $2 \cdot 1 \times \Phi$ $\left.10^{6}\right)$. From these, 13 were found to have the $e^{\text {? }}$ necessary structure for linkage analysis. These families showed typical clinical features of the disease with the development of end stage renalo failure at a mean age of 49.5 years. A total of $24.3 \frac{\mathbb{Q}}{\mathrm{Q}}$ family members and spouses was included in the्g 
genetic linkage analysis, of whom 81 were affected and 67 were at risk of carrying the disease, the total including those whose DNA typing was inferred. Diagnosis of symptomatic cases was confirmed by USS. Asymptomatic at risk subjects were only included when aged over 20 , after informed consent had been obtained. Diagnostic criteria were the finding of a minimum of two cysts in one kidney and one cyst in the other. ${ }^{1}$ Only three subjects were found to be equivocal using USS, of whom one was rescreened independently from the study using computerised tomography (CT) and found to be affected; the other two were not included in the analysis.

DNA ANALYSIS

Blood samples were taken in EDTA tubes and frozen at $-20^{\circ} \mathrm{C}$. Total genomic DNA was prepared from the leucocytes of $20 \mathrm{ml}$ of blood by a triton X100 method. ${ }^{10}$ Restriction enzymes PvuII and RsaI (BRL Ltd, Cambridge) were used to digest DNA, under conditions recommended by the manufacturers, and fragments separated by size using a gel of $0.8 \%$ agarose-ultrapure (BRL Ltd, Cambridge). Southern blots were performed to transfer fragments onto a membrane (N-Hybond, Amersham). DNA was fixed to the membrane by UV irradiation for five minutes and baked for one hour at $80^{\circ} \mathrm{C} \cdot{ }^{32} \mathrm{P}$ labelled probe $3^{\prime} \mathrm{HVR}$ was used for hybridisation. The probe was prepared from a $4 \mathrm{~kb}$ HinfI restriction enzyme fragment, containing the entire $3^{\prime} \mathrm{HVR}$, subcloned into a vector pSP64 ${ }^{11} 12$ and from the $\alpha$ globin gene as a $1.3 \mathrm{~kb}$ fragment in PBR322 (TET Resistant, MRC Haematology Unit, Oxford). ${ }^{13}$

Hybridisation was carried out for approximately 18 hours at $65^{\circ} \mathrm{C}$, with $5 \times 10^{7} \mathrm{CPM} / \mathrm{ml}$ in $\mathrm{N}$-Hybond recommended conditions. Filters were washed for one hour in $2 \times \mathrm{SSC}+0.1 \%$ SDS at room temperature, in $0 \cdot 1 \times \mathrm{SSC}+0 \cdot 1 \%$ SDS at $65^{\circ} \mathrm{C}$ for one hour, and were exposed at $-70^{\circ} \mathrm{C}$ to Fuji $x$ ray film for one to five days, using an X-ograph intensifying screen. Allele inheritance was assessed directly.

\section{Results}

Figs 1 and 2 show the band patterns obtained using the $\alpha$ globin and the 3'HVR probes respectively. No cross overs were seen between the inheritance of alleles detected by these two markers ${ }^{\mathrm{h}}$; the regions they recognise have therefore been considered one locus for analysis, allowing haplotypes to be used. Fig 3 shows the pedigrees analysed with the marker genotypes.

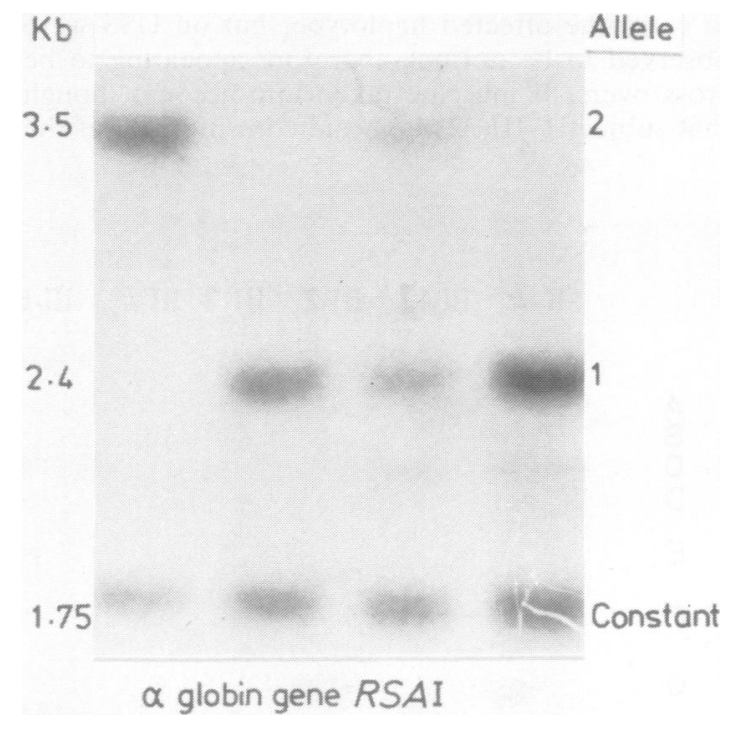

FIG 1 Autoradiography of $\alpha$ globin gene probe hybridised to $5 \mu \mathrm{g}$ genomic DNA digested with Rsal. There is a two allele system $(1,2)$, the frequency of allele 2 being 0.40 in the South Wales population.

The results show linkage between the $\alpha$ globin gene cluster and $A P K D$ locus, with three recombinants out of 83 phase known meioses and a maximum lod score of $\hat{Z}=24 \cdot 187$ at $\hat{\theta}=0.03$ (based on a haplotype between $\alpha$ globin and the $3^{\prime}$ HVR allele inheritance in 12 families).

Non-symptomatic at risk subjects with a prior risk of $50 \%$ that they carried the APKD gene had their risks altered as a function of their age at negative screening with USS $^{1}$ as follows: age 15 to 20 years $0 \cdot 34 ; 20$ to 30 years $0 \cdot 14 ; 30+$ years $0 \cdot 05$. These risks were used in the age of onset correction option of MLINK and LIPED. ${ }^{1415}$ The LIPED programme was used for the calculation of linkage when segregating for sex, and MLINK for calculation of haplotypes. Subjects not at risk were governed by the disease frequency in the general population of 1 in 1000 .

The families studied were analysed with and without using the age of onset probability (tables 1 to 4). No significant difference in recombination fraction was observed, even when analysed separately for each sex (tables 5 to 8). Our results show only three recombinations, all of which were in male meioses.

Subject III.22 in APKD family 1 (1-III.22) and subject II.1 in APKD family 12 (12-II.1) were found 
to carry the affected haplotype, but on USS were observed to be normal, therefore appearing to be cross overs. It must be taken into account though that subject 1-III.22 was scanned using USS at the age of 20 and therefore still has a $14 \%$ risk of expressing the disease in later life. Subject 12-II. was aged 33 when scanned using USS and therefore only has a $<5 \%$ risk.

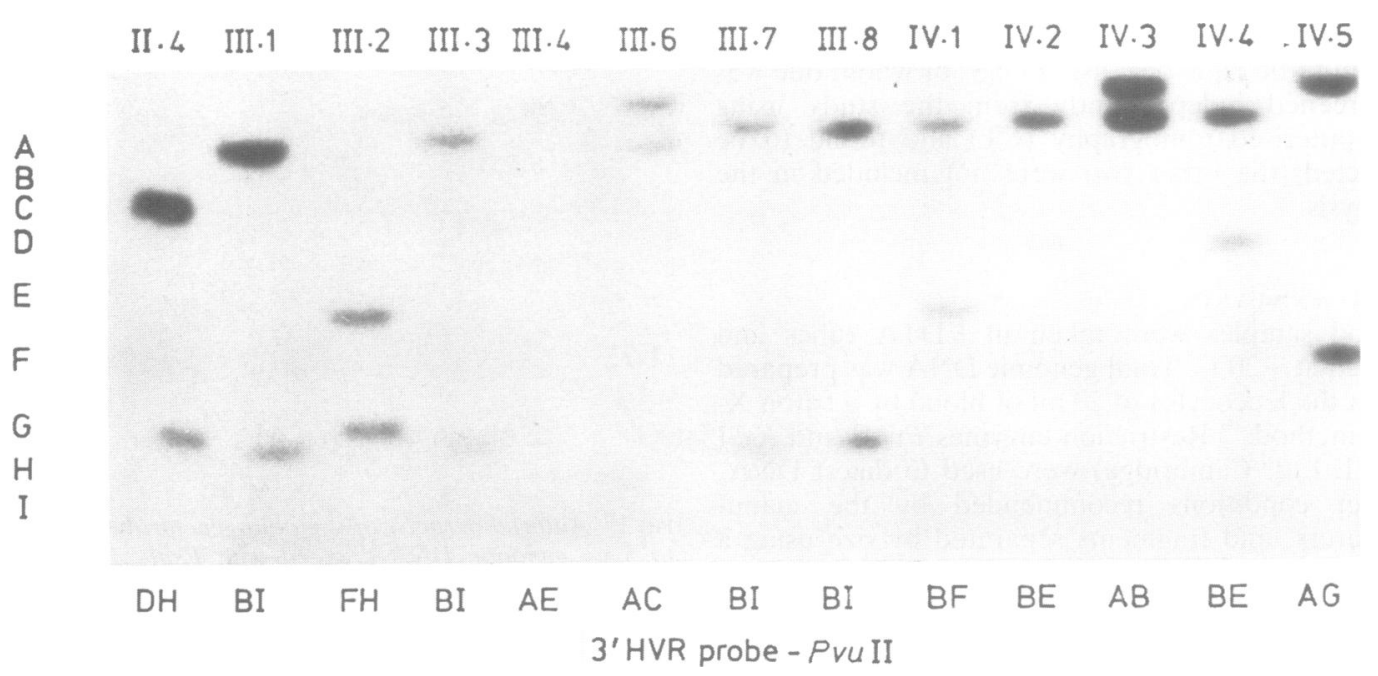

FIG 2 Autoradiograph of $3^{\prime} H V R$ probe hybridised to $5 \mu \mathrm{g}$ DNA digested with Pvull. Members of APKD family 6 (fig 3) are identified above each track. Alleles are named A-I and are specific to the family. The large number of alleles can be attributed to the fact that the 3'HVR region consists of a tandem repeat of a 17 nucleotide base sequence, $\overline{0}$ variability of copy number of the element resulting in polymorphism. The probe hybridises to two allelic fragments in each subject, fragments varying in size from $1.8 \mathrm{~kb}$ to $8 \mathrm{~kb}$ and in all meioses tested, following Mendelian segregation. As the identity of electrophoretically indistinguishable alleles in a highly polymorphic system cannot be assumed, allele frequencies have to be estimated. Because of the great number of alleles being seen in a family using the 3'HVR (in APKD family 1,22 were seen), analysis of the inheritance of the disease with a particular allele is complex. Alleles entering a pedigree from outside, that is, those alleles brought in by the unrelated spouses, were given a common designation to cut 0 down on the number of alleles in a pedigree as far as possible, to aid the computer analysis of the results.

TABLE 1 Individual family lod score, APKD vs a globin, when at risk subjects were simply coded as normal.

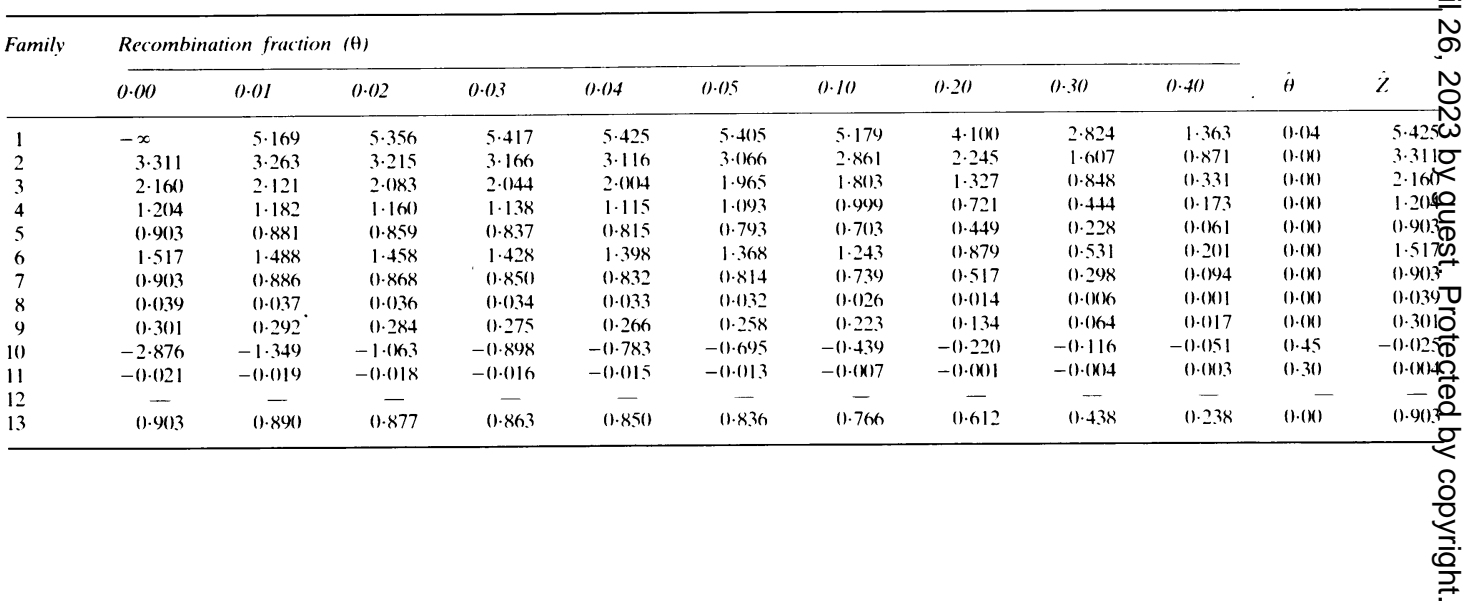




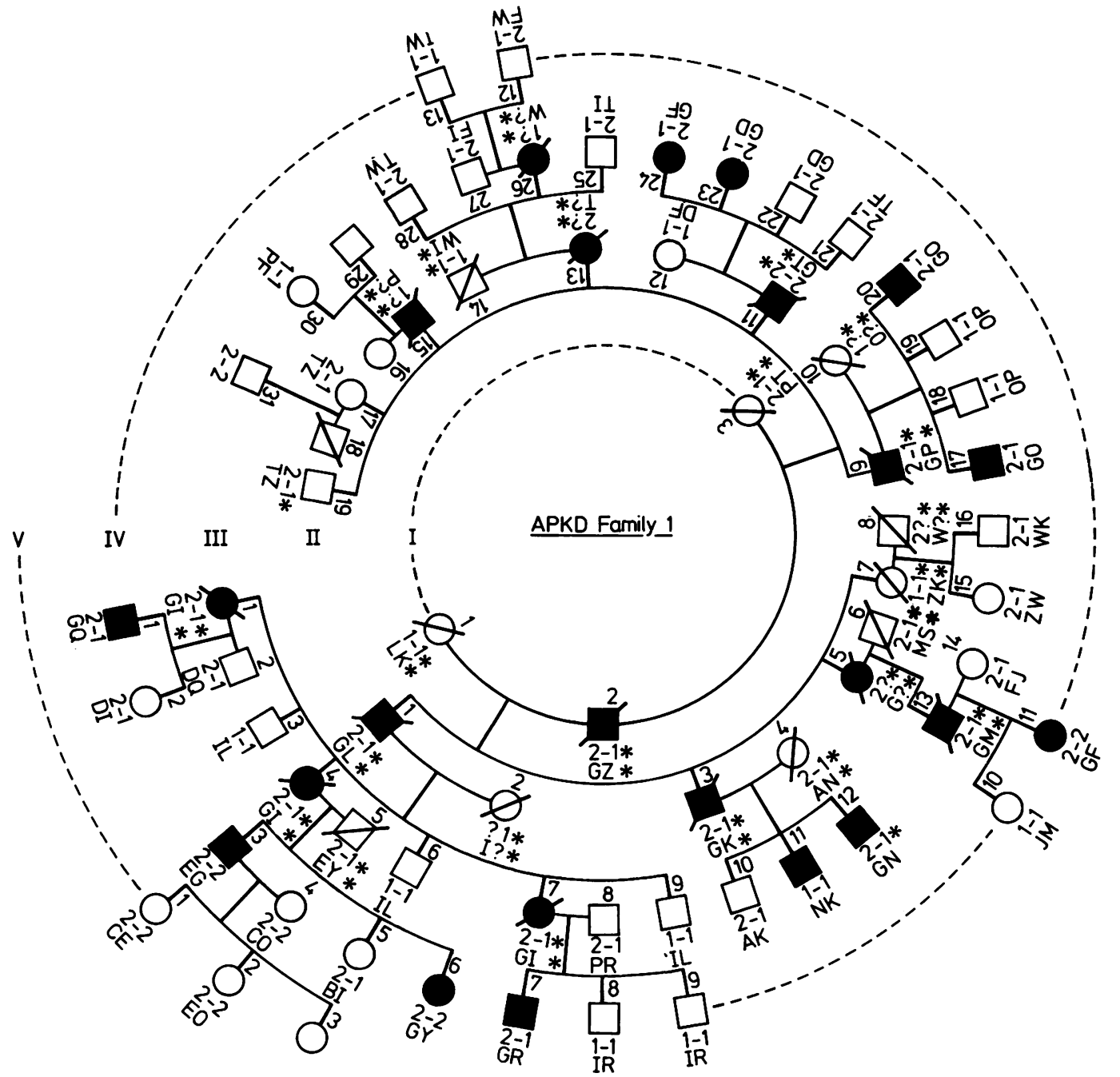

APKD Family 2

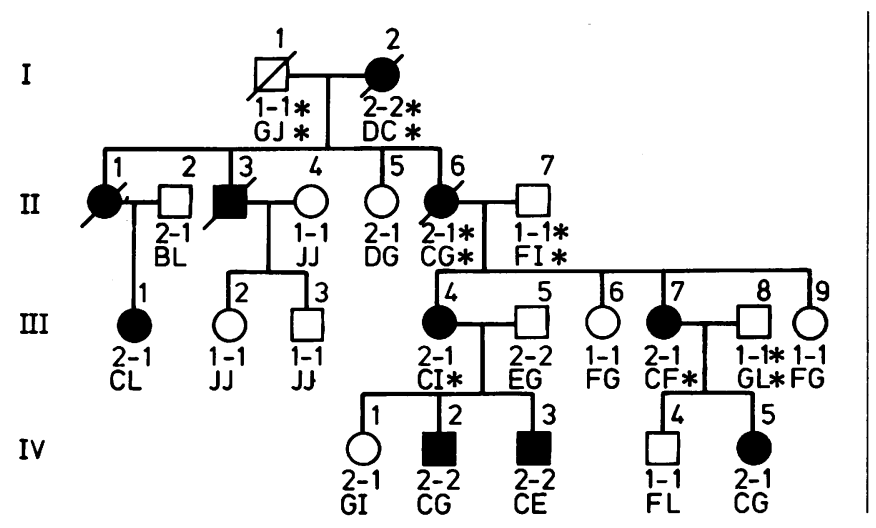

APKD Family 3

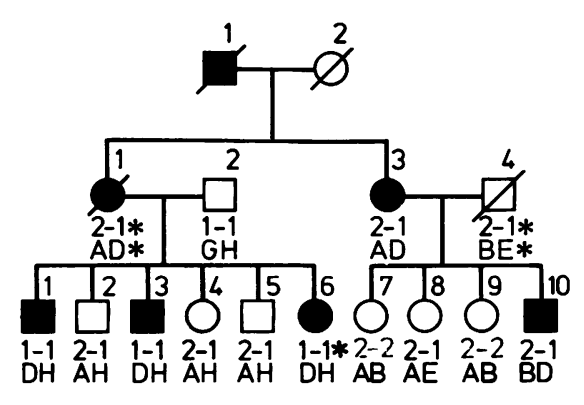




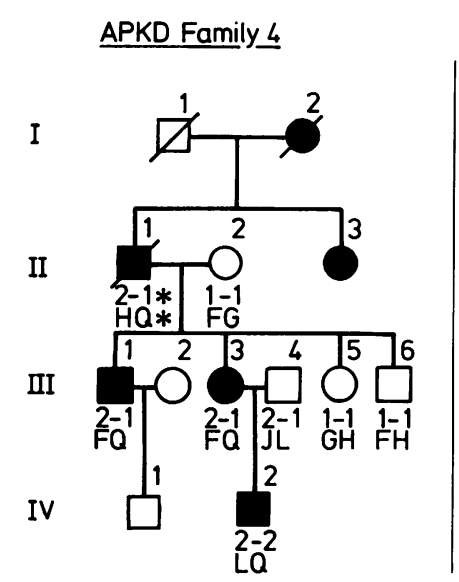

APKD Family $\underline{5}$
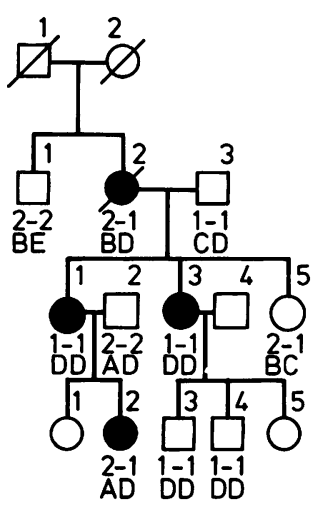

APKD Family 6

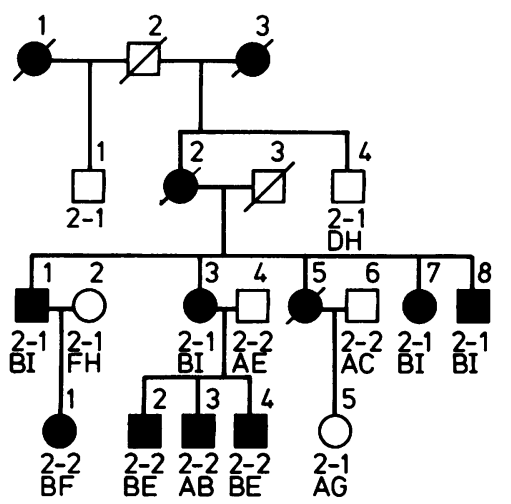

APKD Family 7

I

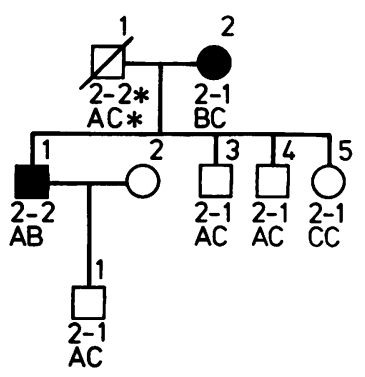

IV
APKD Family $\underline{8}$

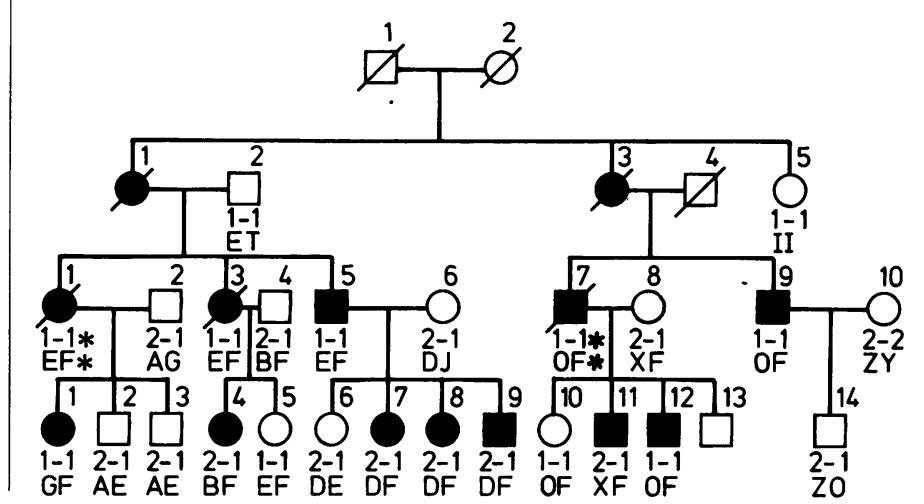

APKD Family 9

I

II

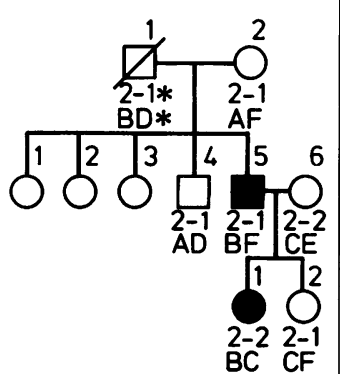

$\underline{\text { APKD Family } 10}$

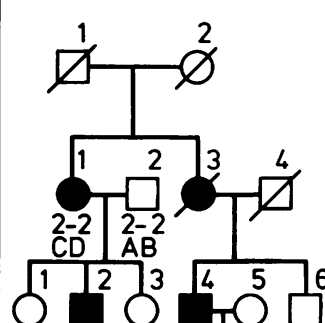

2-2

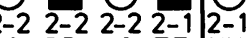

BC BD AC EF XY
APKD Family 11

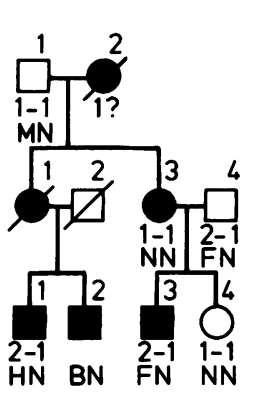

APKD Family 12 APKD Family 13

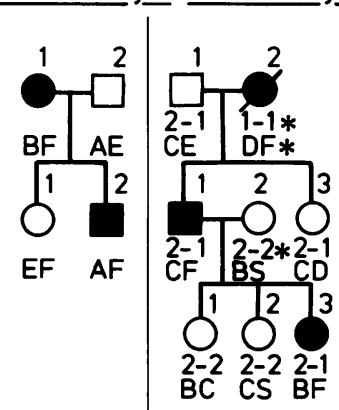

IV

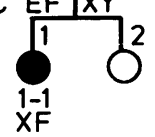

FIG 3 Pedigrees used in the study with the genotypes at the $3^{\prime} H V R(H)$ locus and the a globin $(A)$ locus given for each subject tested and for those that could be inferred $\left(^{*}\right)$. An example of the inheritance of these loci with the disease genß is given by family APKD 6, where the APKD phenotype is seen to segregate with the B/2 haplotype. 
Adult polycystic kidney disease

TABLE 2 Individual family lod score, APKD vs 3'HVR, when at risk subjects were simply coded as normal.

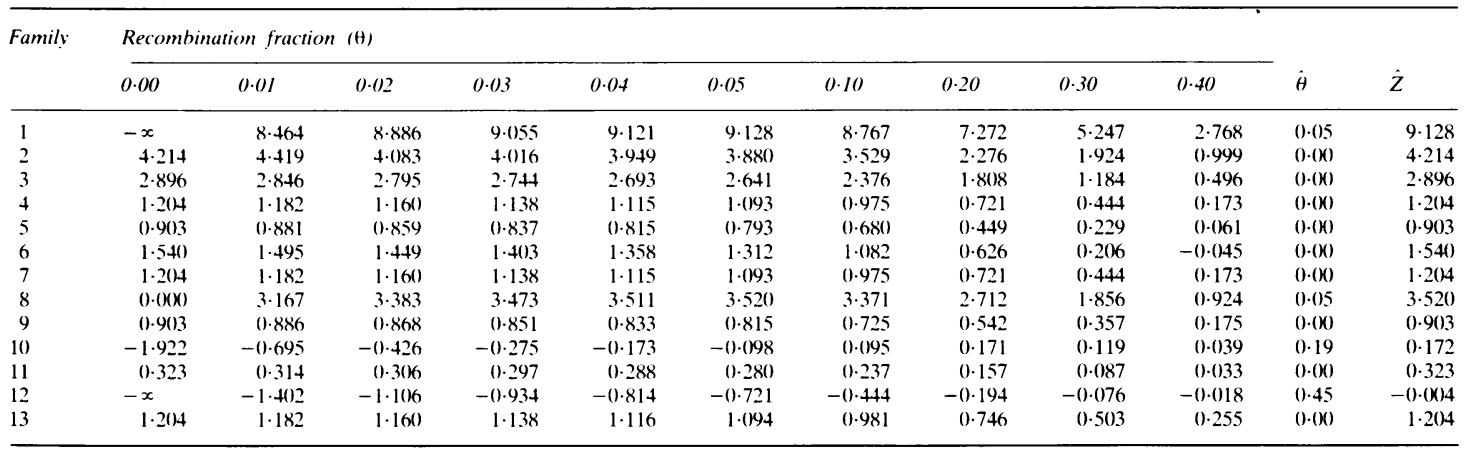

TABLE 3 Individual family lod score, APKD vs $\alpha$ globin, when at risk subjects were given a prior probability from their age.

\begin{tabular}{|c|c|c|c|c|c|c|c|c|c|c|c|c|}
\hline \multirow[t]{2}{*}{ Family } & \multicolumn{10}{|c|}{ Recombination fraction $(\theta)$} & \multirow[b]{2}{*}{$\hat{\theta}$} & \multirow[b]{2}{*}{$\hat{Z}$} \\
\hline & 0.00 & 0.01 & 0.02 & 0.03 & 0.04 & $0 \cdot 05$ & $0 \cdot 10$ & $0 \cdot 20$ & $0 \cdot 30$ & 0.40 & & \\
\hline 1 & $-x$ & 4.869 & $5 \cdot(160)$ & $5 \cdot 125$ & $5 \cdot 138$ & $5 \cdot 121$ & $4 \cdot 841$ & $3 \cdot 887$ & $2 \cdot 668$ & $1 \cdot 279$ & $0 \cdot(14$ & $5 \cdot 138$ \\
\hline 2 & $3 \cdot 170$ & $3 \cdot 123$ & $3 \cdot(176$ & $3 \cdot 029$ & 2.981 & 2.932 & $2 \cdot 683$ & $2 \cdot 140$ & $1 \cdot 528$ & 0.825 & $0 \cdot(00$ & $3 \cdot 170$ \\
\hline 3 & 1.982 & 1.946 & 1.909 & 1.872 & $1 \cdot 835$ & 1.797 & $1 \cdot 605$ & $1 \cdot 197$ & 0.752 & 0.283 & $0 \cdot 00$ & 1.982 \\
\hline 4 & $1 \cdot(090$ & $1 \cdot(070$ & $1 \cdot() 49$ & $1 \cdot(028$ & $1 \cdot 007$ & 0.985 & 0.875 & 0.639 & 0.389 & $0 \cdot 153$ & $0 \cdot 00$ & $1 \cdot 090$ \\
\hline 5 & 0.861 & 0.840 & 0.818 & 0.797 & 0.776 & 0.754 & 0.645 & 0.423 & 0.214 & 0.057 & 0.00 & 0.861 \\
\hline 6 & 1.436 & $1 \cdot 434$ & 1.405 & 1.376 & $1 \cdot 3+6$ & $1 \cdot 317$ & $1 \cdot 164$ & 0.841 & 0.504 & 0.190 & $0 \cdot(0)$ & 1.463 \\
\hline 7 & 0.840 & 0.823 & 0.806 & 0.789 & 0.771 & 0.754 & 0.664 & 0.471 & 0.266 & $0 \cdot(082$ & $0 \cdot(0)$ & $0 \cdot 840$ \\
\hline 8 & 0.039 & $0 \cdot(037$ & 0.036 & 0.034 & $0 .(1) 33$ & 0.032 & 0.025 & $0 \cdot 014$ & 0.006 & $0 \cdot(0) 1$ & 0.00 & 0.039 \\
\hline 9 & 0.244 & 0.237 & 0.229 & 0.222 & 0.214 & 0.207 & 0.171 & $0 \cdot 104$ & $0 \cdot 049$ & $0 \cdot 013$ & 0.00 & $0 \cdot 244$ \\
\hline 10 & $-2 \cdot 876$ & $-1 \cdot 349$ & $-1 \cdot 063$ & -0.898 & -0.783 & -0.695 & -0.439 & -0.220 & -0.11 & $-0 \cdot 051$ & $>0.50$ & $0 \cdot 000$ \\
\hline 11 & $-0 .(121$ & -0.019 & -0.018 & -0.016 & -0.015 & $-0 \cdot(013$ & -0.007 & $0 \cdot 0+1$ & 0.001 & 0.0013 & 0.35 & $0.0(14$ \\
\hline 12 & - & - & - & - & - & - & - & - & - & - & - & - \\
\hline 13 & 0.825 & 0.813 & $0.8(x)$ & 0.788 & $(0.775$ & 0.763 & 0.697 & 0.555 & 0.395 & 0.212 & $0 \cdot(0)$ & 0.825 \\
\hline
\end{tabular}

TABLE 4 Individual family lod score, APKD vs 3'HVR, when at risk subjects were given a prior probability from their age.

\begin{tabular}{|c|c|c|c|c|c|c|c|c|c|c|c|c|}
\hline \multirow[t]{2}{*}{ Family. } & \multicolumn{10}{|c|}{ Recombination fraction $(\theta)$} & \multirow[b]{2}{*}{$\hat{\theta}$} & \multirow[b]{2}{*}{$\hat{Z}$} \\
\hline & 0.00 & 0.01 & $0 \cdot 02$ & 0.03 & 0.04 & 0.05 & $0 \cdot 10$ & $0 \cdot 20$ & $0 \cdot 30$ & 0.40 & & \\
\hline 1 & $-x$ & $9 \cdot(0) 4$ & $9 \cdot 1.55$ & $9 \cdot 178$ & $9 \cdot 147$ & $9 \cdot 085$ & $8 \cdot 550$ & 6.997 & $4 \cdot 987$ & 2.607 & 0.03 & $9 \cdot 178$ \\
\hline 2 & $4 \cdot(1) 73$ & 4.0119 & 3.944 & $3 \cdot 879$ & $3 \cdot 813$ & 3.746 & $3 \cdot 403$ & $2 \cdot 662$ & $1 \cdot 844$ & 0.953 & $0 \cdot(0)$ & 4.073 \\
\hline 3 & $2 \cdot 662$ & 2.614 & $2 \cdot 566$ & $2 \cdot 518$ & $2 \cdot 469$ & $2 \cdot 420$ & $2 \cdot 169$ & 1.635 & $1 \cdot 053$ & 0.426 & $(0 \cdot(0)$ & 1.982 \\
\hline 4 & 1.090 & $1 \cdot(170$ & $1 \cdot(1) 49$ & $1 \cdot 028$ & $1 \cdot 007$ & 0.985 & 0.875 & 0.639 & 0.389 & 0.153 & $(0 \cdot(1)$ & $1 \cdot(190)$ \\
\hline 5 & 0.861 & 0.840 & 0.818 & 0.797 & 0.776 & 0.754 & 0.645 & 0.423 & 0.214 & 0.057 & 0.00 & 0.861 \\
\hline 6 & $1 \cdot 462$ & 1.419 & 1.376 & $1 \cdot 333$ & $1 \cdot 290$ & $1 \cdot 247$ & $1 \cdot(1.30$ & 0.596 & 0.192 & -0.051 & 0.00 & 1.463 \\
\hline 7 & 1.084 & 1.063 & $1 \cdot(1) 42$ & 1.021 & $1 \cdot 0(x)$ & 0.979 & 0.869 & 0.633 & 0.381 & $0 \cdot 143$ & 0.00 & 1.084 \\
\hline 8 & $-x$ & $2.9(0)$ & $3 \cdot 118$ & 3.212 & $3 \cdot 253$ & 3.265 & $3 \cdot 133$ & $2 \cdot 513$ & $1 \cdot 707$ & $(0.840$ & 0.05 & $3 \cdot 265$ \\
\hline 9 & 0.846 & $(1) .829$ & 0.813 & 0.796 & 0.779 & 0.761 & 0.675 & 0.500 & 0.325 & 0.157 & $0 \cdot(0)$ & 0.846 \\
\hline 10 & -1.964 & $-(1.737$ & $-0 \cdot 468$ & -0.316 & -()$\cdot 213$ & -0.138 & 0.0 .58 & $0 \cdot 142$ & 0.101 & 0.033 & 0.19 & 0.142 \\
\hline 11 & (0.323 & $(0.314$ & 0.316 & 0.297 & (). 288 & 0.280 & 0.237 & 0.157 & 0.087 & 0.033 & 0.00 & 0.323 \\
\hline 12 & $-x$ & $-1 \cdot 402$ & $-1 \cdot 1166$ & -0.934 & -0.814 & -0.721 & -0.444 & -0.194 & -0.076 & -0.018 & $>0.50$ & $0 \cdot(x)$ \\
\hline 13 & $1 \cdot 126$ & $1 \cdot 105$ & $1 \cdot(1) 84$ & $1 \cdot() 63$ & $1 \cdot(1) 42$ & $1 \cdot(20)$ & 0.912 & 0.688 & 0.459 & 0.299 & $0 \cdot(0)$ & (). 825 \\
\hline
\end{tabular}


TABLE 5 Linked analysis between APKD and $\alpha$ globin, when at risk subjects were simply coded as normal.

\begin{tabular}{|c|c|c|c|c|c|c|c|c|c|c|c|c|}
\hline & & \multicolumn{10}{|c|}{ Recombination fraction $(\theta)$} & \multirow{2}{*}{$\begin{array}{l}95 \% \\
\text { confidence limit }\end{array}$} \\
\hline & & 0.00 & 0.01 & 0.02 & 0.03 & 0.04 & 0.05 & $0 \cdot 06$ & 0.07 & 0.08 & 0.09 & \\
\hline \multirow[t]{3}{*}{$\alpha$ globin } & M & $-\infty$ & $5 \cdot 608$ & 5.791 & $5 \cdot 846$ & $5 \cdot 848$ & $5 \cdot 819$ & 5.771 & $5 \cdot 7(19$ & $5 \cdot 635$ & $5 \cdot 553$ & $(0) \cdot(0)-0) \cdot 16)$ \\
\hline & $F$ & $10 \cdot 212$ & $10 \cdot 037$ & $9 \cdot 861$ & 9.683 & $9 \cdot 503$ & $9 \cdot 322$ & $9 \cdot 139$ & 8.954 & 8.768 & 8.580 & $(0 \cdot()(1)-0 \cdot(16)$ \\
\hline & $M+F$ & $-\infty$ & $14 \cdot 843$ & $15 \cdot 115$ & $15 \cdot 139$ & $15 \cdot(059$ & 14.920 & 14.743 & 14.539 & $14 \cdot 314$ & $14 \cdot(173$ & $(() \cdot(x)-() \cdot(1) 9)$ \\
\hline \multirow[t]{3}{*}{ 3'HVR } & $\mathbf{M}$ & $-\infty$ & 8.549 & $9 \cdot 236$ & $9 \cdot 546$ & $9 \cdot 698$ & 9.765 & 9.776 & $9 \cdot 748$ & $9 \cdot 690$ & $9 \cdot 608$ & $(0 \cdot() 1-(1) \cdot 1.5)$ \\
\hline & F & $-\infty$ & $15 \cdot 304$ & $15 \cdot 295$ & $15 \cdot 159$ & 14.966 & 14.747 & $14 \cdot 503$ & $14 \cdot 244$ & 13.973 & $13 \cdot 690$ & $(0 \cdot()()-() \cdot(1) 7)$ \\
\hline & $M+F$ & $-\infty$ & $23 \cdot 652$ & $24 \cdot 578$ & $24 \cdot 882$ & 24.928 & $24 \cdot 830$ & $24 \cdot 639$ & $24 \cdot 381$ & $24 \cdot() 74$ & 23.728 & $(0 \cdot 01-1) \cdot(08)$ \\
\hline Haplotype 1 & $M+F$ & $-\infty$ & $24 \cdot 012$ & $24 \cdot 935$ & $25 \cdot 2.37$ & $25 \cdot 280$ & $25 \cdot 178$ & 24.984 & $24 \cdot 723$ & $24 \cdot 412$ & $24 \cdot 162$ & $(0 \cdot(0)-0) \cdot() 8)$ \\
\hline
\end{tabular}

TABLE 6 Linked analysis between the a globin locus and APKD, when at risk subjects were given a prior probability from their age.

\begin{tabular}{|c|c|c|c|c|c|c|c|c|c|c|c|c|}
\hline & & \multicolumn{10}{|c|}{ Recombination fraction $(\theta)$} & \multirow{2}{*}{$\begin{array}{l}95 \% \\
\text { confidence limi }\end{array}$} \\
\hline & & 0.00 & 0.01 & 0.02 & 0.03 & 0.04 & $0 \cdot 05$ & $0 \cdot 06$ & 0.07 & 0.08 & $0 .(09$ & \\
\hline \multirow{2}{*}{$\alpha$ globin } & $\mathrm{F}$ & 9.623 & $9 \cdot 455$ & $9 \cdot 285$ & $9 \cdot 114$ & 8.941 & 8.767 & 8.591 & $8 \cdot 413$ & $8 \cdot 235$ & 8.054 & $(0 \cdot()(1)-0) \cdot(6)$ \\
\hline & $M+F$ & $-\infty$ & $13 \cdot 823$ & $14 \cdot 108$ & $14 \cdot 145$ & $14 \cdot 078$ & 13.953 & $13 \cdot 79()$ & $13 \cdot 6() 1$ & $13 \cdot 390$ & $13 \cdot 163$ & $(0 \cdot(x)-1) \cdot(x))$ \\
\hline \multirow[t]{2}{*}{ 3'HVR } & $\mathbf{M}$ & $-\infty$ & $8 \cdot 844$ & $9 \cdot 264$ & $9 \cdot 429$ & $9 \cdot 489$ & $9 \cdot 490$ & $9 \cdot 452$ & $9 \cdot 386$ & $9 \cdot 299$ & $9 \cdot 196$ & $(0 \cdot()(1)-0 \cdot 15)$ \\
\hline & $\mathrm{M}+\mathrm{F}$ & $-x$ & $23 \cdot 029$ & $23 \cdot 699$ & $23 \cdot 872$ & $23 \cdot 837$ & $23 \cdot 685$ & $23 \cdot 457$ & $23 \cdot 175$ & $22 \cdot 852$ & $22 \cdot 496$ & $((0 \cdot()()-1) \cdot(08)$ \\
\hline Haplotype & $M+F$ & $-\infty$ & $23 \cdot 338$ & $24 \cdot 056$ & $24 \cdot 225$ & $24 \cdot 187$ & $24 \cdot 031$ & $23 \cdot 779$ & $23 \cdot 513$ & $23 \cdot 186$ & $22 \cdot 825$ & $(0 \cdot()()-1) \cdot(1)(8)$ \\
\hline
\end{tabular}

TABLE 7 Linked analysis between a globin locus and APKD, when at risk subjects were simply coded as normal.

\begin{tabular}{|c|c|c|c|c|c|c|c|c|c|c|c|}
\hline & & \multicolumn{8}{|c|}{ Recombination fraction $(\theta)$} & \multirow[b]{2}{*}{$\hat{\theta}$} & \multirow[b]{2}{*}{$\dot{Z}$} \\
\hline & & $0 \cdot 10$ & 0.15 & 0.20 & 0.25 & $0 \cdot 30$ & 0.35 & $0 \cdot 40$ & 0.45 & & \\
\hline \multirow[t]{3}{*}{$\alpha$ globin } & $\mathbf{M}$ & $5 \cdot 464$ & 4.937 & $4 \cdot 316$ & 3.626 & $2 \cdot 880$ & $2 \cdot 096$ & $1 \cdot 3(16$ & 0.583 & (1).(1) & $5 \cdot 848$ \\
\hline & $\mathrm{F}$ & $8 \cdot 390$ & $7 \cdot 415$ & $6 \cdot 395$ & $5 \cdot 331$ & $4 \cdot 228$ & $3 \cdot(197$ & 1.964 & 0.891 & $0 .(k)$ & 10.213 \\
\hline & $M+F$ & $13 \cdot 817$ & $12 \cdot 389$ & 10.779 & $9 \cdot(033$ & $7 \cdot 177$ & $5 \cdot 245$ & $3 \cdot 3(12$ & 1.485 & $0 \cdot() 3$ & $15 \cdot 134$ \\
\hline \multirow[t]{3}{*}{ 3'HVR } & $\mathbf{M}$ & $9 \cdot 510$ & 8.815 & $7 \cdot 898$ & $6 \cdot 827$ & $5 \cdot 622$ & $4 \cdot 305$ & $2 \cdot 888$ & 1.417 & 0.106 & 9.776 \\
\hline & $F$ & $13 \cdot 400$ & $11 \cdot 851$ & $10 \cdot 187$ & 8.439 & $6 \cdot 648$ & $4 \cdot 848$ & $3 \cdot() 81$ & 1.413 & 0.01 & $15 \cdot 3()$ \\
\hline & $M+F$ & $23 \cdot 350$ & $21 \cdot 118$ & 18.499 & $15 \cdot 611$ & $12 \cdot 523$ & $9 \cdot 303$ & $6 \cdot 034$ & $2 \cdot 844$ & $0 \cdot(14$ & $24.92 \gamma$ \\
\hline Haplotype & $M+F$ & 23.679 & $21 \cdot 422$ & 18.772 & $15 \cdot 846$ & $12 \cdot 715$ & $9 \cdot 445$ & 6.123 & 2.882 & $(1) \cdot(1) 4$ & $25 \cdot 281$ \\
\hline
\end{tabular}

TABLE 8 Linked analysis between a globin locus and APKD, when at risk subjects were given a prior probability from their age.

\begin{tabular}{|c|c|c|c|c|c|c|c|c|c|c|c|}
\hline & & \multicolumn{8}{|c|}{ Recombination fraction $(\theta)$} & \multirow[b]{2}{*}{$\dot{\theta}$} & \multirow[b]{2}{*}{$\hat{Z}$} \\
\hline & & $0 \cdot 10$ & 0.15 & $0 \cdot 20$ & $0 \cdot 25$ & 0.30 & $0 \cdot 3.5$ & 0.40 & 0.45 & & \\
\hline \multirow[t]{3}{*}{ a globin } & $M$ & 5.101 & $4 \cdot 6(1)$ & $4 \cdot(127$ & $3 \cdot 378$ & 2.679 & 1.946 & $1 \cdot 212$ & 0.541 & $0 .(1) 4$ & 5.447 ㄷำ \\
\hline & $\mathrm{F}$ & $7 \cdot 872$ & 6.939 & 5.967 & 4.958 & 3.917 & $2 \cdot 8.57$ & 1.806 & 0.820 & 0.00 & $9.623 \mathrm{C}$ \\
\hline & $M+F$ & 12.923 & 11.574 & $10 \cdot(1) 52$ & $8 \cdot 404$ & 6.659 & 4.851 & $3 \cdot(1) 47$ & 1.371 & 0.03 & $14 \cdot 145^{\circ}$ \\
\hline \multirow[t]{3}{*}{ 3'HVR } & $\mathbf{M}$ & 9.078 & $8 \cdot 341$ & $7 \cdot 429$ & $6 \cdot 388$ & $5 \cdot 239$ & 3.495 & $2 \cdot 669$ & $1 \cdot 30.3$ & 0.015 & $9.490 \overline{0}$ \\
\hline & F & $12 \cdot 6(0)$ & $11 \cdot 123$ & 9.535 & $7 \cdot 874$ & 6.176 & 4.481 & $2 \cdot 83.3$ & 1.294 & $0 .(1) 2$ & $14.391 \frac{\vec{D}}{}$ \\
\hline & $\mathrm{M}+\mathrm{F}$ & $22 \cdot 113$ & $19 \cdot 910$ & $17 \cdot 372$ & $14 \cdot 602$ & $11 \cdot 664$ & 8.623 & $5 \cdot 563$ & 2.610 & $(1) \cdot(1) 3$ & $23 \cdot 872$ อุ \\
\hline Haplotype & $M+F$ & $22 \cdot 438$ & $20 \cdot 208$ & $17 \cdot 640$ & 14.833 & $11 \cdot 852$ & $8 \cdot 762$ & 5.650 & $2 \cdot 646$ & 0.013 & $24 \cdot 2258$ \\
\hline
\end{tabular}




\section{Discussion}

These results, like those of Reeders et al, ${ }^{8}$ are conclusive for linkage between $A P K D$ and the $\alpha$ globin gene cluster, suggesting no genetic difference between the disease seen in the South Wales families and those used by Reeders et al. ${ }^{9}$ This strengthens the feasibility of using these markers for the presymptomatic prediction of APKD and for prenatal diagnosis. ${ }^{16}$ The high degree of polymorphism at the $\alpha$ globin/3'HVR locus (in combination $96 \%$ of persons are heterozygous) makes this locus highly informative. There is a risk of error of recombination of around 3\% (confidence limits 0.00 to 0.08 ) but this risk estimate is not age dependent as is USS, which has been the usual screening test until now. At risk subjects under 30 years of age, who are negative on USS, still have a $15 \%$ risk of carrying the gene. ${ }^{1}$ This can now be greatly reduced by the use of DNA markers in combination with USS in suitable families. Closer genetic markers, in particular those flanking the $A P K D$ locus, are currently being sought and should reduce still further the error rate in prediction. Isolation of the gene itself should not only eliminate error due to recombination, but will give rise to a greater understanding of the pathogenesis of the disease.

We would like to thank Dr D R Higgs for supplying the 3'HVR probe, Dr J M Old for supplying the $\alpha$ globin probe, Drs S T Reeders and A L Meredith for their advice, Mr G Wolak for pedigree plotting and data processing, and the patients and their families for their cooperation in the study. This work was supported by the Kidney Research Unit Foundation for Wales (KRUF Wales).

\section{References}

' Bear JC. McManamon P. Morgan J, et al. Age at onset and at ultrasonographic detection of adult polycystic kidney disease: data for genetic counselling. Am J Med Genet 1984;18:45-53.

2 Churchill DN. Bcar JC. Morgan J, Payne RH, McManamon PJ. Gault MH. Prognosis of adult onset polycystic kidncy disease reevaluated. Kidney Int 1984;26:190-3.

3 Danovitch GM. In: Gardner KD, ed Cystic disease of the kidney. New York: Wiley, 1976:125-50.

${ }^{4}$ Dalgaard OZ. Bilateral polycystic disease of the kidneys. Acta Med Scand 1957:158(suppl 328):1-251.

5 Suki WN. Polycystic kidney disease. Kidney Int 1982;22:571-80.

${ }^{6}$ Zerres K. Volpel MC. Weib H. Cystic kidneys. Hum Genet 1984;68:104-35.

${ }^{7}$ Milutinovic J, Agodoa LY. Potential causes and pathogenesis in autosomal dominant polycystic kidney disease. Nephron 1983:33:139-44.

* Reeders ST. Breuning MH. Davies KE, et al. A highly polymorphic DNA marker linked to adult polycystic kidney disease on chromosome 16. Nature 1985;317:542-4.

${ }^{9}$ Reeders ST, Breuning MH, Corney G, et al. Two genetic markers closely linked to adult polycystic kidney disease on chromosome 16. Br Med J 1986:292:851-3.

10 Kunkel LM, Smith KD. Boyer SH, et al. Analysis of human Y chromosome- specific reiterated DNA in chromosome variants. Proc Natl Acad Sci USA 1977:74:1245-9.

"Higgs DR, Goodburn SEY. Wainscoat JS, et al. Highly variable regions of DNA flank the human $\alpha$ globin genes. Nucleic Acids Res 1981;9:4213-24.

12 Nicholls RD. Hill AVS. Clegg JB, Higgs DR. Direct cloning of specific genomic DNA sequences in plasmid libraries following fragment enrichment. Nucleic Acids Res 1985;21:7569-78.

${ }_{13}$ Higgs DR. Wainscoat JS. Flint J. et al. Analysis of the human $\alpha$ globin gene cluster reveals a highly informative genetic locus. Proc Natl Acad Sci USA 1986;83:5165-9.

14 Lathrop GM, Lalouel JM, Ott J. Strategies for multilocus linkage analysis in humans. Proc Natl Acad Sci USA 1984;81:3443-6.

15 Ott J. Estimation of the recombination fraction in human pedigrees: efficient computation of the likelihood for human linkage studies. Am J Hum Genet 1974:26:588-97.

${ }^{16}$ Reeders ST, Gal A, Propping P, et al. Prenatal diagnosis of autosomal dominant polycystic kidney disease with a DNA probe. Lancet 1986;ii:6-8.

Correspondence and requests for reprints to L P Lazarou, Institute of Medical Genetics, University of Wales College of Medicine, Heath Park, Cardiff CF4 4XN. 